\title{
Analysis of Residual Stresses during Heat Treatment of Large Forged Shafts Considering Transformation Plasticity and Creep Deformation
}

\author{
Y. Yanagisawa, ${ }^{a, 1}$ Y. Kishi, ${ }^{a}$ and K. Sasaki ${ }^{\text {b }}$ \\ a The Japan Steel Works, Ltd., Muroran-shi, Hokkaido, Japan \\ ${ }^{\mathrm{b}}$ Hokkaido University, Sapporo-shi, Hokkaido, Japan \\ ${ }^{1}$ yusuke_yanagisawa@jsw.co.jp
}

УДК 539.4

\section{Анализ остаточных напряжений при термообработке больших кованых валов с учетом изменения пластичности и деформации ползучести}

\author{
Ю. Янагисава ${ }^{a}$, Ю. Киши ${ }^{a}$ К. Сасаки \\ а Японский сталелитейный завод, Лтд., Муроран, Хоккайдо, Япония \\ ${ }^{\sigma}$ Университет Хоккайдо, Саппоро, Хоккайдо, Япония
}

Длительное охлаждение при термообработке больших поковок из-за массового эффекта приводит к возникновению деформации ползучести не только за счет высокой температуры, но и вследствие ее изменения. Изменение пластичности и ползучести совместно с фазовыми превращениями стали значительно влияет на распределение напряжений в поковке после термообработки. Разработана конечноэлементная модель с учетом изменения пластичности и ползучести, интегрированная в коммерческую конечноэлементную модель ANSYS c использованием пользовательских подпрограмм. Экспериментально определень характеристики материала при изменении пластичности и ползучести. Для экспериментальной проверки остаточные напряжения в большой поковке сравнивали с таковыми, полученными при моделировании. Результаты моделирования показывают, что остаточные напряжения главным образом вызваны фазовыли превращениями. Установлено, что изменение как пластической деформации, так и деформации ползучести существенно влияет на моделирование остаточных напряжений при термообработке больших кованых валов.

Ключевые слова: термообработка, остаточное напряжение, фазовое превращение, изменение пластичности, ползучесть.

Introduction. During heat treatment of a steel, both the thermal stress and transformation stress occur due to the temperature gradient inside the steel. Special care should be paid to the heat treatment in order to avoid cracking and deformation caused by transient and residual stresses. Therefore, it is important for a computer simulation to estimate both the residual stress and the deformation occurring due to the heat treatment. So far, numerous studies of coupled calculations of metal-thermomechanical behavior have been conducted [1,2], and mainly applied to the quenching process. Although there are many publications on simulation of quenching, most of the research is focused on the small-scale products, such as gear [3], shaft and disc [4], cylinder [5], etc.

Generally, the cooling rate of a large forging decreases due to the mass effect and, especially, the cooling with air cooling and furnace cooling requires several days. Therefore, the creep behavior, which affects the stress distribution, may occur at not only high temperatures but also over transformation temperature ranges. In large forged products, 
heat-treatment simulations considering the phase transformation have also been used to predict the residual stress and distortions. Liu et al. [6] proposed a mathematical model for a rotor shaft during quenching and tempering processes, and designed the efficient process. Fukuya et al. [7] investigated the quenching crack caused by the martensitic transformation of the cylinders. Taschauer et al. [8] predicted the mechanical properties of the turbine discs after heat treatment. However, there are few studies of numerical simulations of the residual stress of large heat-treated forgings considering both the transformation plasticity and creep deformation.

In this study, a finite element method (FEM) model considering both the transformation plasticity and creep was developed. Proposed model was integrated into commercial FEM codes ANSYS via user subroutines. The material properties of the transformation plasticity and creep were also measured experimentally. For experimental verification, the residual stress measurements of the large forged shaft are compared with those of the simulations.

\section{Numerical Modeling.}

1.1. Constitutive Equation. In the thermo-elastoplastic constitutive equations, total strain can be divided into six parts and expressed in incremental form as Eq. (1). Each strain increments are calculated using Eqs. (2)-(6), and the von Mises yield function is expressed by Eq. (7). A kinematic hardening law is used to consider the reverse loading which may occur during the cooling process. The back stress increment is defined as Eq. (8). The transformation plastic strain can be expressed by Eq. (5) which is reviewed by Denis et al. [9], and the creep strain is calculated using Norton's law.

$$
\begin{gathered}
\Delta \varepsilon=\Delta \varepsilon^{e}+\Delta \varepsilon^{p}+\Delta \varepsilon^{t h}+\Delta \varepsilon^{m}+\Delta \varepsilon^{t p}+\Delta \varepsilon^{c}, \\
\Delta \varepsilon^{p}=\Delta \lambda \frac{\partial F}{\partial \sigma}, \\
\Delta \varepsilon^{t h}=\alpha \Delta T \mathbf{I}, \\
\Delta \varepsilon^{m}=\beta \Delta \xi \mathbf{I}, \\
\Delta \varepsilon^{t p}=3 K(1-\xi) \Delta \xi \mathbf{s}, \\
\Delta \varepsilon^{c}=\frac{3}{2} A \bar{\sigma}^{n-1} \Delta t \mathbf{s}, \\
F=\sqrt{\frac{3}{2}(\mathbf{s}-\mathbf{b}):(\mathbf{s}-\mathbf{b})-\sigma_{y},} \\
\Delta \mathbf{b}=\frac{2}{3} H \Delta \varepsilon^{p},
\end{gathered}
$$

where $\Delta \varepsilon^{e}, \Delta \varepsilon^{p}, \Delta \varepsilon^{t h}, \Delta \varepsilon^{m}, \Delta \varepsilon^{t p}$, and $\Delta \varepsilon^{c}$ are the tensor increments of elastic strain, plastic strain, thermal strain, phase transformation strain, transformation plastic strain, and creep strain, respectively, $\Delta \lambda$ is the plastic multiplier, $\alpha$ is the thermal expansion coefficient, $\beta$ is the transformation dilatation, $\mathbf{s}$ is the deviatoric stress tensor, $K$ is the transformation plasticity parameter, $\xi$ is the volume fraction of the new phase, $A$ and $n$ are the creep parameters, $\mathbf{b}$ is the back stress tensor, $\sigma_{y}$ is the yield stress, and $H$ is the plastic hardening modulus. 
1.2. Calculation Flow. Figure 1 shows the calculation flow chart of the subroutine program USERMAT in ANSYS. It is assumed that all plastic strains due to the forging process itself have relaxed and thus it is stress free. At the beginning of the analysis, the phase fraction is defined. Then, the thermal strain and phase transformation strain are calculated considering the phase fraction. After the yield criterion, the implicit integration analysis including both the transformation plastic and creep strains is performed with the return mapping algorithm, since large calculation errors are observed in the explicit integration analysis [10]. The return mapping equations for the elastic and plastic domain are given in Eqs. (9) and (10), and the equivalent stress and the equivalent plastic strain increment are updated. Finally, the consistent tangent modulus is defined. This solution procedure is repeated at each time increment.

$$
\begin{gathered}
g\left(\bar{\sigma}_{i+1}\right)=\bar{\sigma}_{i+1}^{t r i a l}-3 G\left(\Delta \bar{\varepsilon}^{t p}+\Delta \bar{\varepsilon}^{c}\right)-\bar{\sigma}_{i+1}, \\
g\left(\Delta \bar{\varepsilon}^{p}\right)=\frac{\bar{\eta}_{i+1}^{t r i a l}-3 G \Delta \bar{\varepsilon}^{p}}{1+3 G\left(\Delta \bar{\varepsilon}^{t p}+\Delta \bar{\varepsilon}^{c}\right) / \bar{\sigma}_{i+1}}-\sigma_{y}-H \Delta \bar{\varepsilon}^{p},
\end{gathered}
$$

where $\bar{\sigma}_{i+1}^{\text {trial }}$ is the elastic trial stress, $\bar{\eta}_{i+1}^{\text {trial }}$ is the elastic trial relative stress, $\bar{\sigma}_{i+1}$ is the equivalent stress, $G$ is the shear modulus, and $H$ is the plastic hardening modulus.

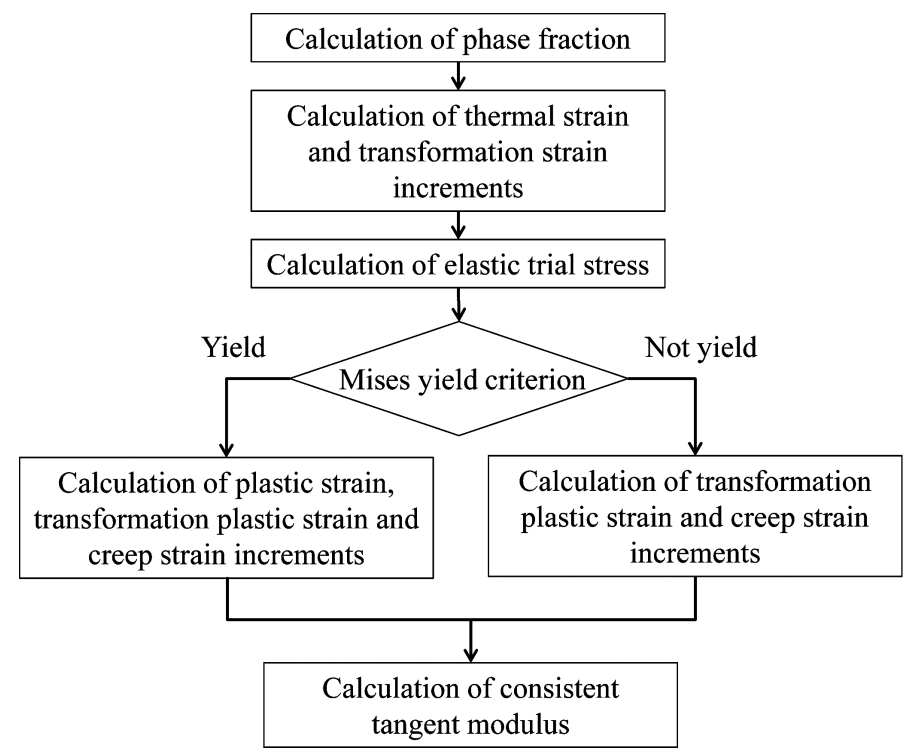

Fig. 1. The calculation flow chart of the subroutine program USERMAT.

1.3. Determination of Material Parameters. The material parameters for numerical modeling are decided from the following procedures. The materials are $\mathrm{Ni}-\mathrm{Cr}-\mathrm{Mo}-\mathrm{V}$ steel (ASTM A470M steel). It is assumed that a microstructure is bainite due to slow cooling rate of the large forgings.

1.3.1. Transformation Kinetics. The Johnson-Mehl-Avrami-Kolmogorov (JMAK) equation is used to depict the transformation kinetics of the bainitic transformation for an isothermal condition. For consecutive cooling transformation kinetics, it is assumed that the cooling curves can be divided into small time intervals in which the kinetics are isothermal. The transformed phase fraction at the current time step is calculated from a fictitious time depending on the fraction transformed up to the end of the previous time step [11]. 


$$
\begin{gathered}
\xi_{i+1}=1-\exp \left[-k\left(T_{i+1}\right)\left(\tau_{i+1}+\Delta t_{i+1}\right)^{n}\right], \\
\tau_{i+1}=\left(-\frac{\ln \left(1-\xi_{i}\right)}{k\left(T_{i+1}\right)}\right)^{1 / n},
\end{gathered}
$$

where $\xi$ is the volume fraction of bainite, $k$ and $n$ are material-dependent parameters.

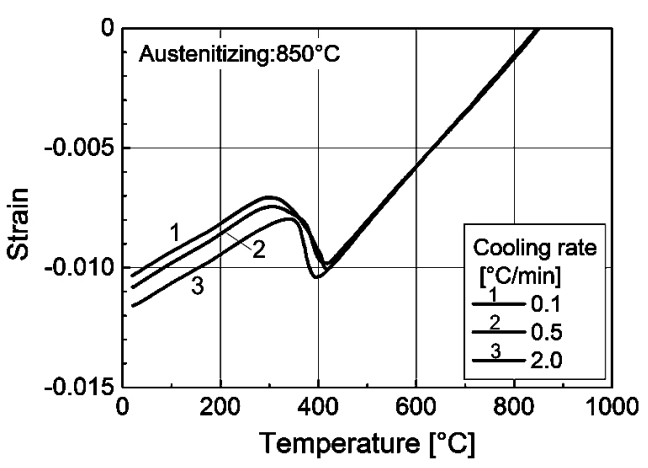

Fig. 2

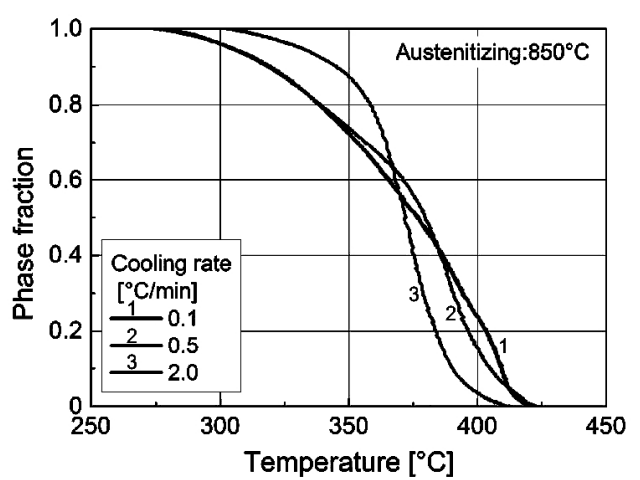

Fig. 3

Fig. 2. Temperature-strain diagram measured by a dilatometric test.

Fig. 3. Phase fraction of bainite.

The material parameters $(k, n)$ are determined using the least square method to minimize the differences between the calculated volume fraction and the measured ones. Figure 2 shows a temperature-strain diagram measured by a dilatometric test, which cools specimens from the austenitizing temperature to room temperature. The transformed fraction was estimated using Eq. (13), and Fig. 3 shows the volume fractions of bainite at various cooling rates. Figure 4 shows a comparison between the measured and the calculated phase fractions. Obtained parameters are shown in Eq. (14). In the cooling rate range at 0.1 to $0.5^{\circ} \mathrm{C} / \mathrm{min}$, the calculated volume fraction corresponds to the measured one.

$$
\begin{gathered}
\Delta \xi=\frac{\Delta \varepsilon-\alpha(\xi) \Delta T}{\beta(T)}, \\
k(T)=\exp \left[-2 \cdot 10^{-4}(T-290)^{2}-0.27\right], \quad n=0.17 .
\end{gathered}
$$

1.3.2. Transformation Plasticity. The transformation plasticity is proportional to the applied stress which is smaller than the yield stress of the austenite phase [12]. Therefore, the transformation plasticity parameter $K$ is experimentally identified from the relation between the transformation plastic strain and the applied stress. The following tests were performed to identify the transformation plasticity using a hot working simulator of Thermec mastor_z. The specimens were heated up to $850^{\circ} \mathrm{C}$ and cooled down rapidly to $450^{\circ} \mathrm{C}$, and a stress was applied at $450^{\circ} \mathrm{C}$ and maintained at a constant level. The cooling rate was $2{ }^{\circ} \mathrm{C} / \mathrm{min}$ during phase formation. The transformation plastic strain can be calculated as the deviation between the stress-free total strain value and the strain value with a small applied stress. As shown in Fig. 5, linear relations link the applied stress and the transformation plastic strain under tensile or compressive stresses. The obtained results 


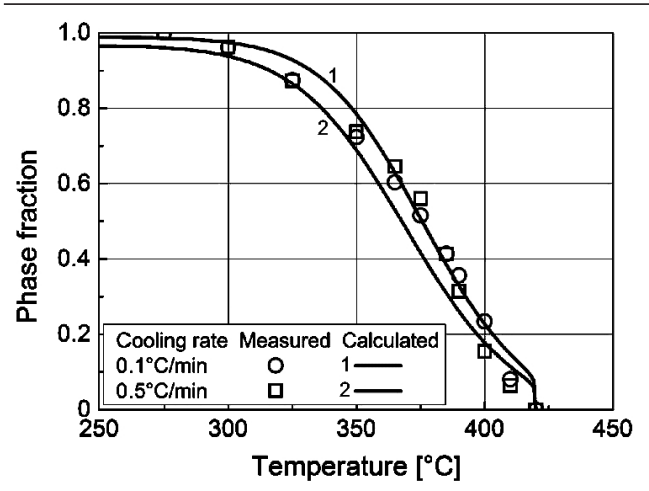

Fig. 4

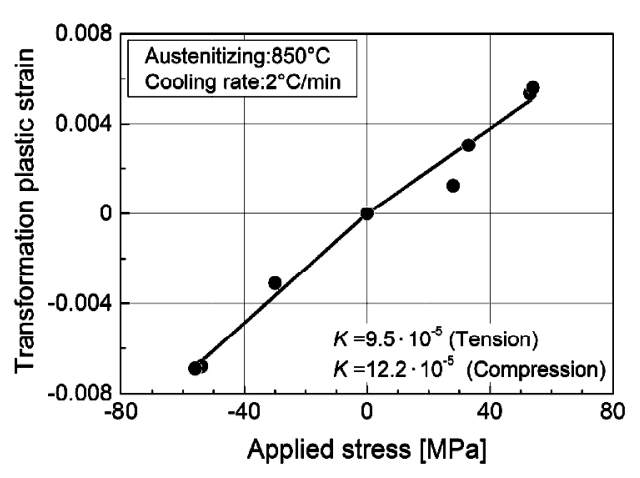

Fig. 5

Fig. 4. Measured and calculated phase fraction.

Fig. 5. Relation between applied stress and transformation plastic strain of bainite transformation.

give $9.5 \cdot 10^{-5} \mathrm{MPa}^{-1}$ to a value of $K$ under the tensile stress, and $12.2 \cdot 10^{-5} \mathrm{MPa}^{-1}$ under the compressive stress. Because the difference in the values of $K$ under tensile and compressive stress is small, the value of $K$ under the tensile stress was used in this analysis.

1.3.3. Creep Property. The creep parameters were determined from a creep database for the austenite phase of SUS304 steel [13] due to each body-centered cubic crystal structure, and from the results of the stress relaxation test for the bainite phase. The material for the relaxation test was heat-treated at $850^{\circ} \mathrm{C}$ and cooled at $1{ }^{\circ} \mathrm{C} / \mathrm{min}$ in order to obtain the bainite phase, and machined to the specimen with a diameter of $6 \mathrm{~mm}$. The initial stresses, which were $0.1 \%$ of the yield stress at test temperature, were applied to the specimen and the constraint was maintained at a constant level for $24 \mathrm{~h}$. The creep strain rate was calculated from the relaxed stress as a function of time.

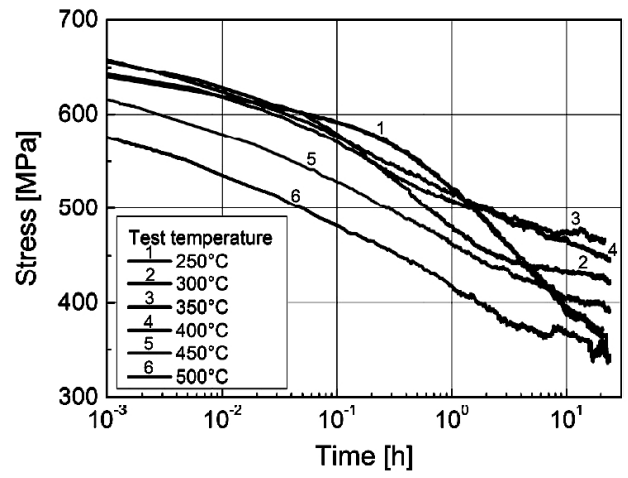

Fig. 6

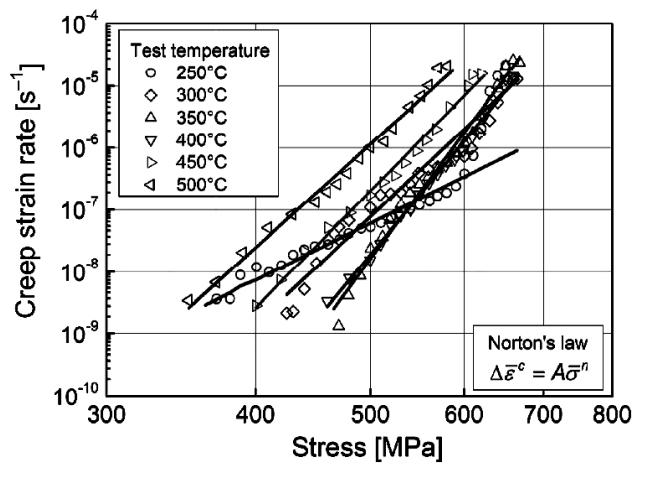

Fig. 7

Fig. 6. Stress relaxation curves.

Fig. 7. Fitting with Norton's law for stress relaxation properties.

Figures 6 and 7 show the stress relaxation curves, and the relationship between stress and creep strain rate at various temperatures, respectively. The stress relaxation behavior is different between the high stress and the low stress regions under temperatures of 250 and $300^{\circ} \mathrm{C}$, in contrast to the results under temperatures from 350 to $500^{\circ} \mathrm{C}$. This is because about $5 \%$ austenite is inevitably retained in the specimen, and the stress relaxations occur 
$\mathrm{T}$ a b 1 e 1

\section{Creep Parameters}

\begin{tabular}{|c|c|c|c|}
\hline \multirow{2}{*}{$\begin{array}{c}\text { Temperature } \\
\left({ }^{\circ} \mathrm{C}\right)\end{array}$} & \multirow[t]{2}{*}{ Phase } & \multicolumn{2}{|c|}{ Creep parameter } \\
\hline & & $A$ & $n$ \\
\hline \multirow[t]{2}{*}{250} & \multirow[t]{8}{*}{$\alpha$} & $1.71 \cdot 10^{-33}$ & 9.5 \\
\hline & & $6.0 \cdot 10^{-33}$ & 9.2 \\
\hline \multirow[t]{2}{*}{300} & & $5.46 \cdot 10^{-56}$ & 17.8 \\
\hline & & $1.1 \cdot 10^{-59}$ & 19.1 \\
\hline 350 & & $3.7 \cdot 10^{-78}$ & 25.8 \\
\hline 400 & & $7.59 \cdot 10^{-71}$ & 23.1 \\
\hline 450 & & $8.37 \cdot 10^{-60}$ & 19.4 \\
\hline 500 & & $4.49 \cdot 10^{-53}$ & 17.2 \\
\hline 600 & \multirow[t]{3}{*}{$\gamma$} & $2.96 \cdot 10^{-24}$ & 10.0 \\
\hline 650 & & $1.5 \cdot 10^{-22}$ & 10.0 \\
\hline 700 & & $7.0 \cdot 10^{-21}$ & 10.0 \\
\hline
\end{tabular}
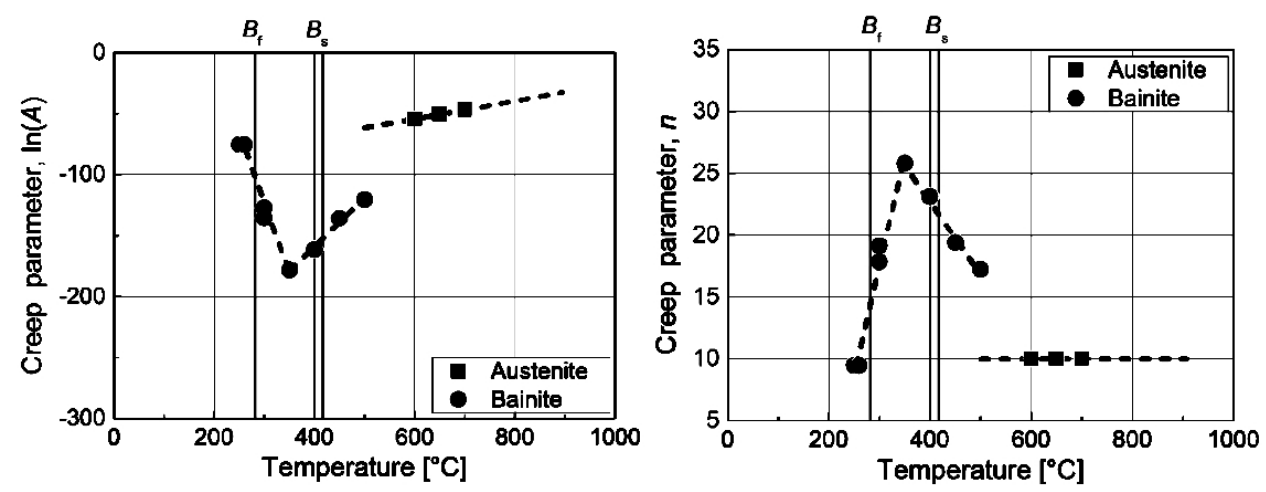

Fig. 8. Creep parameters $A$ and $n$.

due to both the retained austenite transformation and the creep deformation from 250 to $300^{\circ} \mathrm{C}$. These stress-relaxation behaviors are expressed by a creep constitutive equation using Norton's law, which can well explain the creep behavior under the low stress as shown in Fig. 7. Table 1 and Fig. 8 show the creep parameters used in the analysis.

1.3.4. Stress-Strain Curve. The stress-strain curves are described using the RambergOsgood equation (15) and calculated according to the linear mixture rule for the phase mixture. The comparison of experimental and calculated stress-strain curves for the bainite and austenite phase are shown in Fig. 9, and the parameters of the Ramberg-Osgood equation are listed in Table 2.

$$
\bar{\varepsilon}^{p}=\varepsilon_{0}\left(\frac{\bar{\sigma}}{D}\right)^{m}
$$

where $\varepsilon_{0}, D$, and $m$ are the Ramberg-Osgood parameters. 
$\mathrm{T}$ a b 1 e 2

Ramberg-Osgood Parameters

\begin{tabular}{|c|c|c|c|c|c|c|c||}
\hline \hline \multicolumn{2}{|c|}{ Temperature $\left({ }^{\circ} \mathrm{C}\right)$} & 20 & 200 & 400 & 500 & 700 & 900 \\
\hline \multirow{2}{*}{$\varepsilon_{0}$} & $\alpha$ & \multicolumn{7}{|c||}{0.0001} \\
\cline { 2 - 9 } & $\gamma$ & \multicolumn{7}{|c||}{} \\
\hline \multirow{2}{*}{$D$} & $\alpha$ & 480 & 530 & 490 & 420 & - & - \\
\cline { 2 - 9 } & $\gamma$ & - & - & - & 8.9 & 13.8 & 17.8 \\
\hline \multirow{2}{*}{$m$} & $\alpha$ & 6.0 & 6.8 & 7.2 & 7.1 & - & - \\
\cline { 2 - 9 } & $\gamma$ & - & - & - & 2.0 & 2.8 & 6.1 \\
\hline
\end{tabular}

$\mathrm{T}$ a b 1 e 3

Thermophysical Properties in Heat Transfer Analysis

\begin{tabular}{||c|c|c|c|c|c|c|c|c||}
\hline \hline Temperature $\left({ }^{\circ} \mathrm{C}\right)$ & & 20 & 200 & 300 & 400 & 500 & 700 & 900 \\
\hline $\begin{array}{c}\text { Specific heat } \\
(\mathrm{J} /(\mathrm{kg} \cdot \mathrm{K}))\end{array}$ & $\alpha$ & 447 & 519 & 554 & 596 & 644 & - & - \\
\cline { 2 - 11 } & $\gamma$ & - & 540 & 554 & 568 & 582 & 611 & 639 \\
\hline $\begin{array}{c}\text { Thermal conductivity } \\
(\mathrm{W} /(\mathrm{m} \cdot \mathrm{K}))\end{array}$ & $\alpha$ & 35.3 & 37.8 & 37.2 & 36.6 & 34.9 & - & - \\
\cline { 2 - 10 } & $\gamma$ & - & 18.2 & 19.6 & 21.0 & 22.4 & 25.3 & 28.1 \\
\hline Density $\left(\mathrm{kg} / \mathrm{m}^{3}\right)$ & - & \multicolumn{7}{|c||}{7860} \\
\hline $\begin{array}{c}\text { Transformation latent } \\
\text { heat }(\mathrm{kJ} / \mathrm{kg})\end{array}$ & - & \multicolumn{7}{|c|}{140} \\
\hline $\begin{array}{c}\text { Heat transfer coefficient } \\
\left(\mathrm{W} /\left(\mathrm{m}^{2} \cdot \mathrm{K}\right)\right)\end{array}$ & - & 8 & 18 & 24 & 31 & 41 & 70 & 115 \\
\hline \hline
\end{tabular}

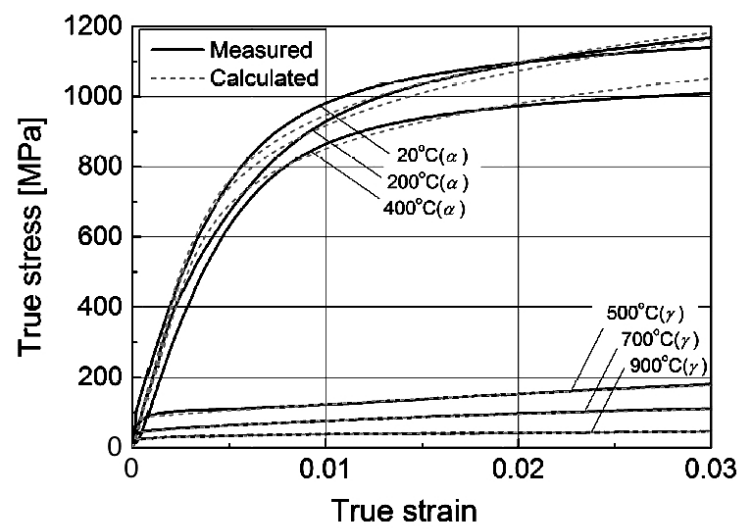

Fig. 9. Comparison of measured and calculated stress-strain curves.

1.3.5. Temperature Distribution. The heat transfer analysis was carried out for temperature distribution of the large forged shaft as shown in the section below. The thermophysical properties such as the specific heat and the thermal conductivity were measured experimentally. The heat transfer coefficients in the calculations were estimated using the inverse analysis method, which is chosen so that the simulated temperature has the same value as the measured temperature. The thermophysical properties used in analysis are presented in Table 3 . Figure 10 shows a comparison of the cooling curves 


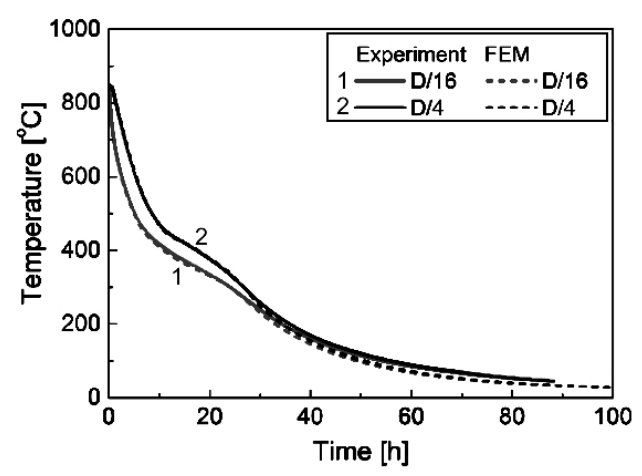

a

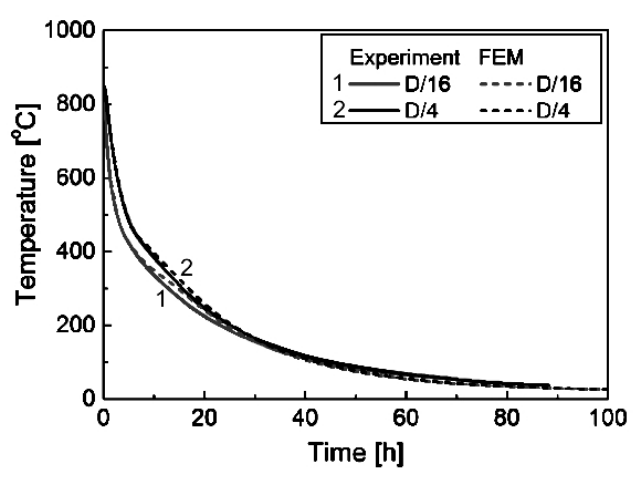

b

Fig. 10. Comparison of experimental and FEM analysis cooling curves: (a) $\varnothing 1280 \mathrm{~mm}$; (b) $\varnothing 1080 \mathrm{~mm}$.

between the experiment and the FEM analysis. The cooling time to room temperature is approximately $100 \mathrm{~h}$, and the average cooling rate at the transformation temperature area was 0.17 to $0.25{ }^{\circ} \mathrm{C} / \mathrm{min}$. The temperatures predicted at both the center and the surface show good agreement with the experimental results. In addition, the effect of the transformation latent heat on the temperature was well simulated as shown in Fig. 10.

\section{Analysis of Residual Stress of Large Forged Shaft.}

2.1. Heat Treatment of Large Forged Shaft. Figure 11 shows the large forged shaft used in this study. The material was Ni-Cr-Mo-V steel (ASTM A470M steel). The ingot was forged using a 14,000-ton hydraulic free press. Then, the forging was heat treated at $850^{\circ} \mathrm{C}$ for $27 \mathrm{~h}$ and air-cooled. The prior austenite grain size number of the material is about 6.0. Figure 12 shows a continuous cooling transformation (CCT) diagram of the ASTM A470M with thermometry results. It can be presumed that the forgings had microstructures of bainite referring Fig. 12.

I Thermometry point

O Stress measurement point

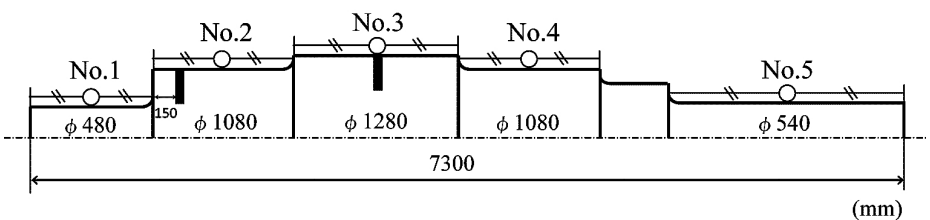

Fig. 11. Schematic illustration of large forged shaft.

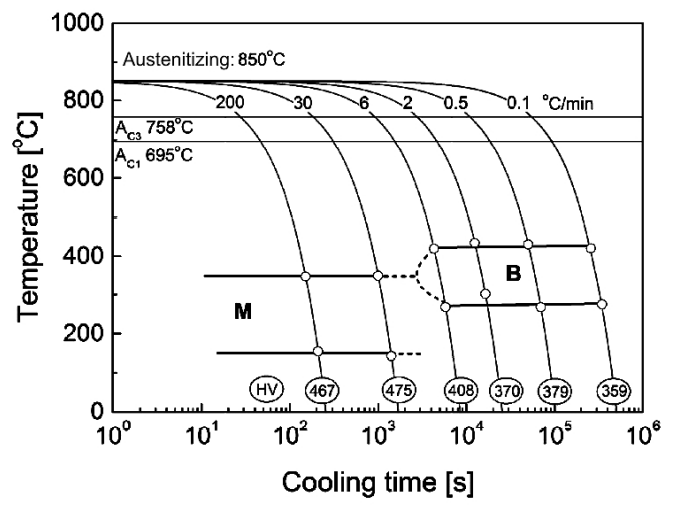

Fig. 12. CCT diagram of A470M steel. 


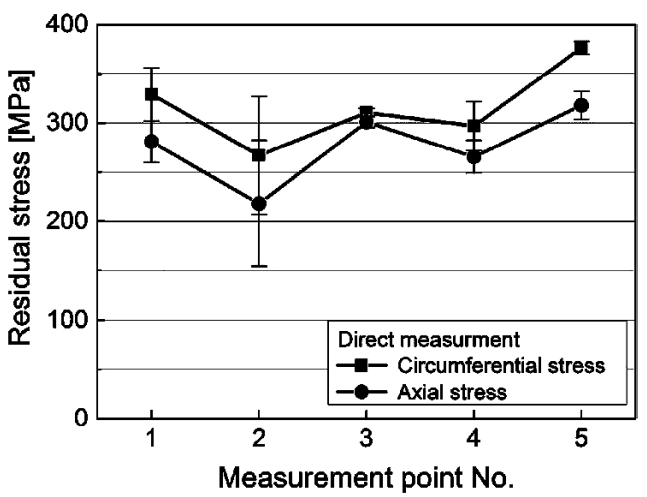

Fig. 13. Residual stress measured at the outer surface using the ring-core method.

The residual stresses were measured in five places on the outer surface using the ring-core method. The annular groove, which is $16 \mathrm{~mm}$ inner diameter, $7 \mathrm{~mm}$ in depth, was machined around a strain gauge. The residual stresses were calculated from the relaxed strains. Figure 13 shows the residual stress measured on the outer surface. The mean axial and circumferential stresses are about 220 to $380 \mathrm{MPa}$ tensile stresses, respectively. The residual stresses of the small diameter parts (Nos. 1 and 5) were equal or higher than that of maximum diameter part (No. 3). In spite of the relatively large difference in diameter, there is no significant correlation between the diameter and the residual stress.

2.2. Verification of Residual Stress Calculation. In order to clarify the relative effects of the transformation plasticity and creep, three analysis conditions were chosen: (a) eliminating the transformation plastic strain and creep strain in Eq. (1), (b) considering only the transformation plastic strain in Eq. (1), and (c) considering both strains in Eq. (1). The mechanical properties used in analysis are presented in Table 4.

$\mathrm{T}$ a b 1 e 4

Mechanical Properties in Thermo-Elastoplastic Analysis

\begin{tabular}{|c|c|c|c|c|c|c|c|c|}
\hline \multicolumn{2}{|l|}{ Temperature $\left({ }^{\circ} \mathrm{C}\right)$} & 20 & 200 & 300 & 400 & 500 & 700 & 900 \\
\hline \multirow[t]{2}{*}{ Elastic modulus (GPa) } & $\alpha$ & 208 & 195 & 187 & 180 & 173 & - & - \\
\hline & $\gamma$ & - & 182 & 173 & 164 & 155 & 137 & 119 \\
\hline \multirow[t]{2}{*}{ Poisson's ratio } & $\alpha$ & \multicolumn{7}{|c|}{0.3} \\
\hline & $\gamma$ & \multicolumn{7}{|c|}{0.3} \\
\hline \multirow[t]{2}{*}{ Yield stress $(\mathrm{MPa})$} & $\alpha$ & 457 & 490 & 475 & 436 & 373 & - & - \\
\hline & $\gamma$ & - & 123 & 121 & 108 & 88 & 44 & 26 \\
\hline \multirow{2}{*}{$\begin{array}{l}\text { Thermal expansion } \\
\text { coefficient }\left({ }^{\circ} \mathrm{C}^{-1}\right)\end{array}$} & $\alpha$ & \multicolumn{7}{|c|}{$1.47 \cdot 10^{-5}$} \\
\hline & $\gamma$ & \multicolumn{7}{|c|}{$2.24 \cdot 10^{-5}$} \\
\hline Transformation dilatation & - & \multicolumn{7}{|c|}{0.0068} \\
\hline
\end{tabular}

The stresses analyzed are shown in Fig. 14. There is a little residual stress without transformation plasticity, and the difference is on the dangerous side in terms of cracking from the surface. The simulated residual stresses are tension when the transformation plasticity is considered, but the tensile stress analyzed was higher than the measurements 


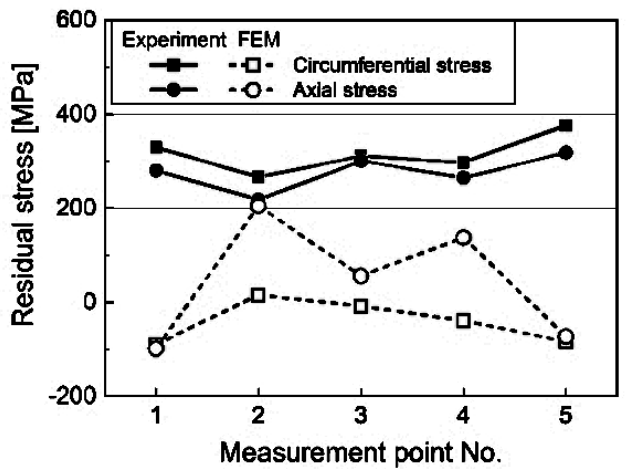

a

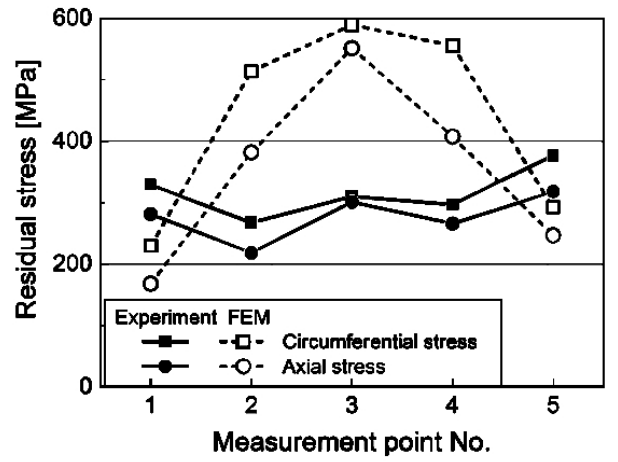

b

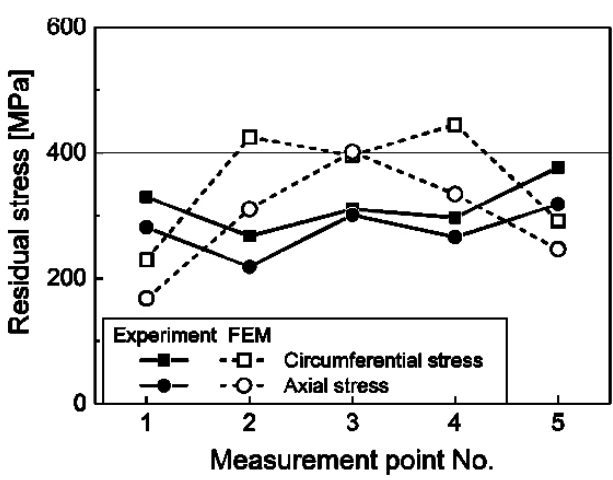

$\mathrm{c}$

Fig. 14. Comparison of residual stress between experiment and FEM analysis: (a) analysis without transformation plasticity and stress relaxation; (b) analysis with transformation plasticity only; (c) analysis with transformation plasticity and stress relaxation.

from the large diameter parts. The analyzed surface stresses tend to approach the measured stresses when the stress relaxation is considered. The effect of stress relaxation at the surface of large diameter parts was higher than that at the surface of the small parts, because the surface stresses increase with increasing diameter.

As shown in the above, both the transformation plastic strain and the creep strain play important roles in simulating the residual stress in the heat treatment of a large forged shaft. However, there is a quantitative difference between the analyzed and experimental values. The difference may come from the effect of stress on bainite formation. This problem is discussed in the next section.

2.3. Effect of Stress on Phase Transformation. It is well known that both the stress and plastic deformation affect the phase transformation [14]. However, this effect is not considered in this analysis since the phase transformation is investigated under zero stress. It is difficult to measure the phase transformation experimentally under the simulated heat treatment conditions of a large forged shaft. For the investigation of this effect, the following simplifying assumptions were made. To consider the effect of stress on bainite transformation, the kinetics of bainite can be given by Eq. (16) as a modified JMAK equation with an additional stress term $[15,16]$,

$$
k(T, \bar{\sigma})=k(T, 0)(1+A \bar{\sigma}),
$$

where $\bar{\sigma}$ is an equivalent stress and $A$ is a material parameter. 


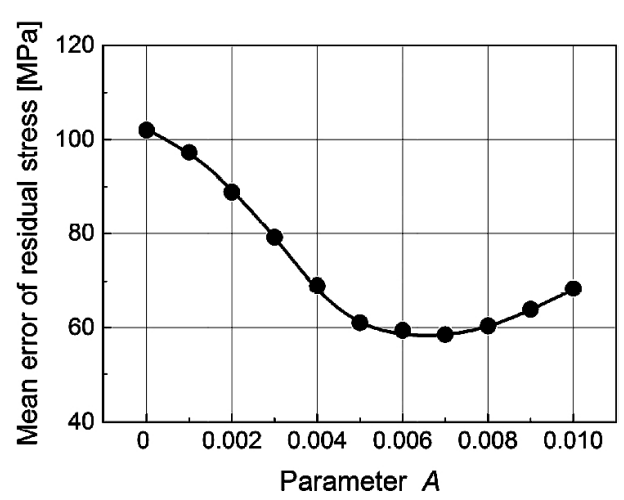

Fig. 15

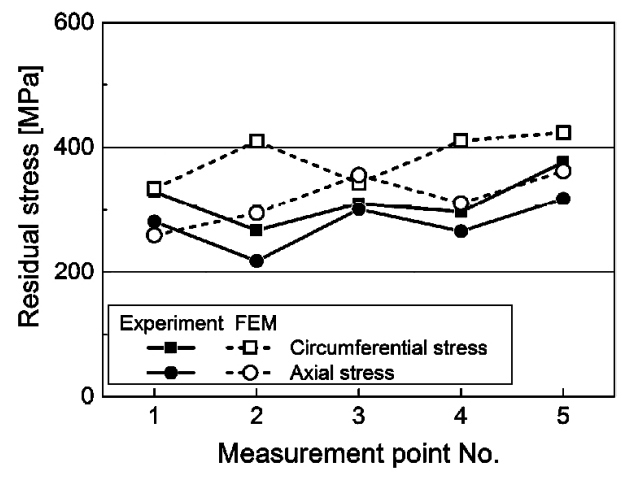

Fig. 16

Fig. 15. Mean error of residual stress varying parameter $A$ in modified JMAK equation under applied stress.

Fig. 16. Residual stress considering stress dependence on the bainite transformation.

Repeated calculations were carried out varying the value of $A$ in order to minimize the mean error between the calculated stresses and the measured ones. Figure 15 shows the mean error of the residual stresses while varying parameter $A$. The analysis results using the optimized value of $A(A=0.007)$ are shown in Fig. 16. The analyzed stresses are approximately the same as the measured ones when the effect of stress on phase transformation is considered. Since the phase transformation is accelerated due to the stress, the surface stresses increase with increasing in the transformation plasticity effect. In addition, the stress of a large diameter piece reaches the same level as that of a small diameter piece due to the stress relaxation. It is confirmed that the calculated residual stresses show a good agreement with the measurements. However, more experimental data are required to clarify the details.

Conclusions. A FEM model considering both the transformation plasticity and creep deformation was developed to predict the residual stress of a large forged shaft. The validity of the calculation was verified by comparing the residual stress between experiment and analysis. As a result, the following conclusions are obtained:

1. The constitutive equation for both the transformation plasticity and creep were successfully incorporated into FEM code of ANSYS.

2. The material parameters of the transformation plasticity and creep were measured experimentally and applied to the analysis.

3. The mean surface stresses of the large forged shaft were about 220 to $380 \mathrm{MPa}$ in tension, and no significant correlation was seen between diameter and residual stress.

4. There is a little residual stress without transformation plasticity, while considering the transformation plasticity gives the same tendency for the simulated residual stress as that of the experimental one.

5. The analyzed surface stresses tend to approach the measured one when the stress relaxation is considered.

6. It is confirmed that the calculated residual stresses show a good agreement with the measurements when the effect of stress on phase transformation is considered.

\section{Резюме}

Тривале охолодження при термообробці великих поковок внаслідок масового ефекту призводить до виникнення деформації повзучості не тільки за рахунок високої 
температури, а й внаслідок іiі зміни. Зміна пластичності і повзучості разом із фазовими перетвореннями сталі суттєво впливає на розподіл напружень у поковці після термообробки. Розроблено скінченноелементну модель 3 урахуванням зміни пластичності і повзучості, інтегровану в комерційну скінченноелементну модель ANSYS із використанням підпрограм для користувачів. Експериментально визначено характеристики матеріалу при зміні пластичності і повзучості. Для експериментальної перевірки залишкові напруження у великій поковці порівнювали з отриманими при моделюванні. Результати моделювання показують, що залишкові напруження в основному зумовлені фазовими перетвореннями. Установлено, що зміна як пластичної деформації, так і деформації повзучості суттєво впливає на моделювання залишкових напружень при термообробці великих кованих валів.

1. T. Inoue and Z. Wang, "Coupling between stress-temperature-metallic structures during processes involving phase-transformations," Mater. Sci. Technol., 1, No. 10, 845-850 (1985).

2. S. Denis, S. Sjöström, and A. Simon, "Coupled temperature, stress, phasetransformation calculation model numerical illustration of the internal-stresses evolution during cooling of a eutectoid carbon-steel cylinder," Metall. Trans. A, 18, No. 7, 1203-1212 (1987).

3. M. Fukumoto, M. Yoshizaki, H. Imataka, et al., "Three-dimensional FEM analysis of helical gear subjected to the carburized quenching process," J. Soc. Mater. Sci., 50, No. 6, 598-605 (2001).

4. R. Pietzsch, M. Brzoza, Y. Kaymak, et al., "Simulation of the distortion of long steel profiles during cooling," J. Appl. Mech., 74, No. 3, 427-437 (2007).

5. C. Simsir and C. H. Gur, "3D FEM simulation of steel quenching and investigation of the effect of asymmetric geometry on residual stress distribution," J. Mater. Process. Tech., 207, 211-221 (2008).

6. C. C. Liu, X. J. Xu, and Z. Liu, "A FEM modeling of quenching and tempering and its application in industrial engineering," Finite Elem. Anal. Des., 39, No. 11, 1053-1070 (2003).

7. M. Fukuya, T. Terasaki, H. Imamura, and A. Fujita, "Relation between transient stress and quenching cracks in cylinders generated by quenching," J. Jpn Soc. Naval Arch. Ocean Eng., 6, 119-129 (2007).

8. M. Taschauer, G. Panzl, V. Wieser, et al., "New perspectives on heat treatment of large forgings," in: Proc. of the 19th International Forgemaster Conference, Japan (2014), pp. 1-10.

9. S. Denis, E. Gautier, A. Simon, and G. Beck, "Stress phase-transformation interactions-basic principles, modeling, and calculation of internal-stresses," Mater. Sci. Technol., 1, No. 10, 805-814 (1985).

10. Y. Kawaragi, M. Fukumoto, and K. Okamura, "Effect of implicit integration scheme in residual stress analysis of quenching considering transformation plasticity and kinematic hardening," J. Soc. Mater. Sci., 64, No. 4, 258-265 (2015).

11. M. Umemoto, K. Horiuchi, and I. Tamura, "Transformation kinetics of bainite during isothermal holding and continuous cooling," Tetsu-to-Hagane, 68, No. 3, 461-470 (1982).

12. G. W. Greenwood and R. H. Johnson, "The deformation of metals under small stresses during phase transformations," Proc. Roy. Soc. A, 283, 403-422 (1965). 
13. Data Sheets on the Elevated-Temperature Properties of 18Cr-8Ni Stainless Steel for Boiler and Heat Exchanger Seamless Tubes (SUS 304H TB), NRIM Creep Data Sheet, No. 4B (1986).

14. S. Denis, E. Gautier, S. Sjöström and A. Simon, "Influence of stresses on the kinetics of pearlitic transformation during continuous cooling," Acta Metall., 35, No. 7, 1621-1632 (1987).

15. C. C. Liu, K. F. Yao, and Z. Liu, "Quantitative research on effects of stresses and strains on bainitic transformation kinetics and transformation plasticity," Mater. Sci. Technol., 16, No. 6, 643-647 (2000).

16. T. Y. Hsu, "Additivity hypothesis and effects of stress on phase transformations in steel," Curr. Opinion in Solid State and Mater. Sci., 9, No. 6, 256-268 (2005).

Recived 18. 02. 2017 